\title{
Outdoor education wzmocnieniem realizacji zrównoważonego rozwoju
}

\author{
Małgorzata Jagodzińska*, Anna Strumińska-Doktór \\ Wydział Ochrony Zdrowia i Nauk Społecznych, Państwowa Uczelnia Zawodowa im. Ignacego Mościckiego w Ciechanowie \\ ul. Wojska Polskiego 51, 06-400 Ciechanów \\ *gosia.jagod@gmail.com・ORCID: MJ 0000-0002-9741-4378; AS-D 0000-0001-7292-2352
}

\begin{abstract}
Streszczenie
Wadą edukacji w dzisiejszej szkole jest przekaz słowny oraz badania i eksperymenty w murach szkolnych. Uczniowie mają mało okazji do badania i doświadczania rzeczywistości w naturalnych warunkach. Czynny udział uczniów uaktywnia, zaciekawia i daje poczucie sprawstwa. Wspólne planowanie ekspedycji, wycieczek i gier terenowych jest czynnikiem kształtującym więzi i zaufanie w grupie. Zajęcia w plenerze pozwalają na odkrycie zainteresowań i talentów. Pedagogika Outdoor education (OE) staje się coraz bardziej popularna, w Polsce przyjmuje różne nazwy: edukacja na świeżym powietrzu, edukacja poza klasą, edukacja plenerowa, zajęcia terenowe, pedagogika przygody. Podczas zajęć terenowych dzieci zdobywają zarówno wiedzę, jak i umiejętności. Podstawą są zespołowe działania, w tym gry zespołowe w plenerze. Wykorzystywane są naturalne przeszkody, a środowisko naturalne to bogactwo pomocy dydaktycznych. Nauka w terenie przez doświadczanie rzeczywistości pozwala w szczególny sposób zrozumieć prawa rządzące naturą, które jednoznacznie generują podejście rozwoju zrównoważonego w życiu człowieka. Niestety studenci nie są przygotowani do podejmowania zadań w terenie. Jako młodzi nauczyciele, rzadko organizują wycieczki i traktują je jako rekreację i przerwę w nauce. Świadomość nauczycieli związana z nowymi nurtami w pedagogice, w tym Outdoor education, jest coraz większa, niestety wraz nią nie zmieniły się kompetencje związane z prowadzeniem zajęć w plenerze. W artykule zostaną zaprezentowane wyniki badań przeprowadzonych wśród studentów pedagogiki wczesnoszkolnej i przedszkolnej realizujących kształcenie w Białymstoku i Łodzi. Celem badań było zgromadzenie informacji na temat wiedzy studentów 0 OE i ich oczekiwaniach w tym zakresie w kontekście kształtowania i podwyższania jakości kształcenia.
\end{abstract}

\section{Słowa kluczowe}

zrównoważony rozwój, edukacja poza salą (outdoor education)

\section{Wprowadzenie}

Człowiek z przyrodą związany jest na co dzień, jest jej częścią, dzięki niej żyje i funkcjonuje. Od wczesnego dzieciństwa środowisko przyrodnicze jest mu najbliższe, najbardziej naturalne, a dzięki potrzebom poznawczym i dziecięcej spostrzegawczości wrasta w świat przyrody naturalnie i z wielkim zainteresowaniem. Zaspokojenie dziecięcej potrzeby ciekawości i weryfikowania nowej wiedzy powinno być wyzwaniem dla nauczycieli edukacji przyrodniczo-społecznej do podejmowania priorytetowych działań w tym zakresie. Tym bardziej, że środowisko przyrodnicze, $\mathrm{z}$ uwagi na swoje zasoby, może być postrzegane jako pracownia dydaktyczna, która uczy wiedzy 
o świecie, pozwala na wzbogacanie słownika oraz kształtowanie nowych pojęć. Uczy też pokory, cierpliwości i wyrozumiałości. Zaszczepia pragnienie poznawania świata i otwartość na nowe wiadomości. W przyrodzie zachodzą zjawiska wzmacniające rozwój myślenia przyczynowo-skutkowego. Dziecko uczy się dostrzegać nie tylko zależności i następstwa różnych zjawisk, lecz także zależności wśród zwierząt i roślin, w ekosystemie. Dzięki bezpośredniemu kontaktowi z przyrodą niosącą zaskakujące sytuacje dzieci samodzielnie odkrywają te zależności. Dostrzegają problemy, uczą się ich rozwiązywania. Środowisko w naturalny sposób wzmaga aktywność dziecka, a dziecko w naturze czuje się dobrze.

O znaczeniu edukacji ekologicznej i przyrodniczej w rozwoju dzieci mówi się od lat. Niestety nie jest to zagadnienie, które przekonało nauczycieli, aby część procesu edukacyjnego przenieść w teren.

Oprócz edukacji przyrodniczej i ekologicznej w szkołach i przedszkolach realizowana jest edukacja dla zrównoważonego rozwoju. Pewnym ułatwieniem dla realizacji zagadnień realizowanych w ramach tej edukacji były, wprowadzone podstawą programową z 1999 r., ścieżki edukacyjne. Miały one być formą nauczania interdyscyplinarnego. Szczególnie chodziło o treści ważne, aktualne, dotyczące obszarów społecznych. Treści były wydzielone w podstawie programowej, ale nikt (może poza dyrektorem) nie był odpowiedzialny za ich realizację. Nie były też wskazane formy realizacji ścieżek edukacyjnych, ani częstotliwość realizacji tych zagadnień. Ścieżki były bardzo krytykowane przez nauczycieli i dość szybko zniknęły z dokumentów oświatowych. Mimo to ścieżka ekologiczna pozwoliła na zwrócenie uwagi nauczycieli na aktualność problematyki zrównoważonego rozwoju i na dość niską świadomość proekologiczną społeczeństwa w tym zakresie. Edukacja dla zrównoważonego rozwoju została wpisana do programów szkolnych, głównie do programu wychowawczo-profilaktycznego. W podstawie programowej można znaleźć odniesienie do wychowania w kontekście akceptacji i szacunku dla drugiego człowieka, kształtowania postaw szacunku dla środowiska przyrodniczego, w tym upowszechniania wiedzy o zasadach zrównoważonego rozwoju (Rozporządzenie MEN z 14 lutego 2017 r.).

Rozwój cywilizacyjny i technologiczny coraz częściej uświadamia, że brak równowagi w środowisku przyrodniczym, społecznym i ekonomicznym daje negatywne konsekwencje. Szkoły podjęły wyzwanie dekady dla zrównoważonego rozwoju i starają się, mimo upływu lat, realizować edukację:

- umożliwiającą zdobycie wiedzy, umiejętności i kompetencji dających podstawy wszechstronnego rozwoju,

- dostępną na takim samym poziomie dla wszystkich uczniów na wszystkich etapach edukacyjnych oraz dostępną dla środowiska lokalnego, w tym rodziców,

- kształtującą postawę obywatelską, demokratyczną, odpowiedzialność za siebie i grupę,

- promującą naukę przez całe życie,

- wyrównującą szanse edukacyjne i wspierającą harmonijny rozwój jednostki.

W ostatnim czasie nowoczesna dydaktyka wprowadziła nowy kierunek w działaniach pedagogicznych, dotyczący kreowania wielostronnego nauczania, uczenia się, polegającego na poznawaniu rzeczywistości poprzez odkrywanie, przeżywanie zjawisk i działanie w środowisku życia człowieka. Takie podejście oparte jest na przeświadczeniu, że problemy środowiska naturalnego można zrozumieć tylko i wyłącznie będąc w ich centrum, poprzez samodzielne poznanie. Dlatego ważne jest, aby we współczesnej szkole, nie tylko w edukacji środowiskowej, lecz także w zakresie innych edukacji, łączyć treści teoretyczne z praktyką.

Nauczyciele prowadzą więc zajęcia w terenie, ale z przeprowadzonych badań wynika, że tylko kilka razy w roku. Najczęściej zajęcia poza klasą szkolną prowadzą nauczyciele edukacji wczesnoszkolnej i nauczyciele 
wychowania fizycznego. Pedagodzy wybierają formy dla siebie najprostsze, ale pozwalające na realizację zapisów statutowych, boją się prowadzić zajęcia lekcyjne poza murami szkoły ze względu na ewentualne nieposłuszeństwo uczniów (Strumińska-Doktór i Doktór 2016: 43).

Współczesna edukacja wymaga innego spojrzenia na potrzeby dzieci. Istnieje potrzeba poszukania sposobów ułatwiających uczenie się oraz wzmacniających umiejętności. Bez aranżacji w sposób szczególny przestrzeni edukacyjnej i nowego podejścia do procesu uczenia się, opartego na dużej aktywności uczniów i ich samodzielności w drodze do rozwoju, efekty edukacji dla zrównoważonego rozwoju będą niskie.

Prowadzenie zajęć lekcyjnych wyzwalających aktywność dzieci, wymagających od nich zaangażowania i kreatywności, jest możliwe dzięki odpowiednio przygotowanemu nauczycielowi, szczególnie w zakresie rozszerzonych kompetencji metodycznych. Dobór odpowiednich metod nauczania i uczenia się może okazać się warunkiem sukcesu. Edukacja kształtuje świadomość i ukazuje zależności nie tylko w przyrodzie, lecz także między ludźmi i ich środowiskiem. Zainteresowanie się edukacją przyrodniczą jest ważnym elementem zrównoważonej edukacji. W środowisku przyrodniczym można nauczyć się odpowiedzialności, wzmacniać wiarę we własne umiejętności i doświadczać sukcesu. Zaangażowanie w zadania prośrodowiskowe daje poczucie spełnienia i motywuje do dalszych działań na rzecz przyrody. Najczęściej warsztat pracy młodego nauczyciela jest niewystarczający, aby skutecznie edukować dzieci i młodzież. Nauczyciel, który sam nie ma ukształtowanych kluczowych kompetencji w tym zakresie, nie poradzi sobie z kształtowaniem ich u dzieci i młodzieży. Kompetencje ujęte w Europejskiej Ramie Odniesienia w zakresie nauk przyrodniczych dotyczą zdolności i chęci wyjaśniania świata przyrody z wykorzystaniem istniejącego zasobu wiedzy i stosowanych metod (w tym obserwacji i eksperymentów), w celu formułowania pytań i wyciągania wniosków opartych na dowodach. Kompetencje w zakresie nauk przyrodniczych, technologii i inżynierii obejmują rozumienie zmian powodowanych przez działalność człowieka oraz rozumienie swojej odpowiedzialności jako obywatela (Zalecenie Rady z 22 maja 2018 r.).

Ważna jest umiejętność obserwacji przyrody w terenie, dokonywania badań, stosowania metody projektów i tworzenie środowiska sprzyjającego uczeniu się. Nauczyciel musi u siebie kształtować te kompetencje, które chciały kształtować u swoich uczniów oraz te, które pozwolą na aktywizację grupy, wdrażanie do krytycznego myślenia, rozbudzanie ciekawości świata oraz badania przyrody w terenie. Systematycznie organizowane zajęcia terenowe stają się ważnym czynnikiem rozwoju i niezastąpioną przestrzenią do interakcji społecznych i budowania więzi grupowych, dają poczucie satysfakcji z kontaktu z przyrodą. Zajęcia terenowe, aby spełniły swoje zadanie, powinny być orgaznizowane bez względu na pogodę, powinny umożliwiać upust kumulowanej energii i uwrażliwiać na piękno przyrody. Dzieci szybko nabywają odporność na niesprzyjające warunki, a niepogoda też może rozbudzać ciekawość świata i radość z przebywania w naturalnym środowisku. Przyszły nauczyciel musi sam lubić przyrodę i czerpać radość z przebywania w naturalnych warunkach. Jeśli będzie w swoich poczynaniach autentyczny, sprawi, że jego podopieczni będą także czerpali przyjemność z obcowania z przyrodą.

Studenci posiadają dość niski poziom wiedzy o przyrodzie i środowisku (Jelinek 2014: 54-56), a jeszcze niższy poziom umiejętności metodycznych z zakresu wprowadzania w procesie dydaktycznym treści przyrodniczych i treści na temat zrównoważonego rozwoju w ciekawy i atrakcyjny sposób. Sytuację można poprawić poprzez wprowadzenie do programu studiów przedmiotów prowadzonych metodą warsztatową w naturalnych warunkach, które pozwolą studentom nabyć umiejętności prowadzenia zajęć poza klasą szkolną oraz pomogą zbudować 
bazę merytoryczną umożliwiającą biegłe poruszanie się w niezbędnej wiedzy przyrodniczej. Takim rozwiązaniem może być outdoor education.

Głównym celem pracy jest ukazanie outdoor education jako czynnika wzmacniającego realizację wytycznych zrównoważonego rozwoju na gruncie edukacyjnym.

Outdoor education (OE) to dziedzina pedagogiki popularna m.in. w Niemczech, Norwegii, Wielkiej Brytanii oraz w USA. W Polsce nie ma jednoznacznego określenia na ten rodzaj pedagogiki, ale w piśmiennictwie zagranicznym także występują kłopoty definicyjne.

Outdoor education wykorzystywane jest w kształceniu nauczycieli edukacji przedszkolnej i wczesnoszkolnej w Europie Zachodniej. Równie rozpowszechniony jest nurt adventure education. Badacze nie są zgodni co do korzeni obu nurtów i różnicy między nimi. Na użytek artykułu nie będziemy zastanawiać się nad problemami natury semantycznej i lingwistycznej, mimo że tłumaczenie na język polski tych pojęć nie jest jednoznaczne. W polskiej literaturze występują m.in. edukacja przygodą, pedagogika przygody, wychowanie plenerowe, plenerowość, edukacja przygodowa, turystyka przygodowa, pedagogika przeżyć, zajęcia w terenie, edukacja poza klasą (Leśny 2014: 41). Pedagogika przygody i pedagogika przeżyć bardzo prężnie rozwijają się na Zachodzie. Za ojca nurtu outdoor education uważany jest Kurt Hahn, niemiecki pedagog (1886-1974). Wyznaczył on podstawowe zasady w pedagogice przeżyć:

- kładzenie nacisku na odpowiedzialność pedagoga za wychowanka - ma go prowadzić, ma nim kierować, powinien być dla niego wzorem,

- stwarzanie okazji do przeżywania i uczenia się zarazem - uczeń powinien na lekcji nie tylko przeżywać, lecz także działać,

- angażowanie całej osobowości podczas działania,

- learning by doing - istotne jest nie tylko uczenie się przez działanie, lecz także działanie wspólne, które buduje więź, daje możliwość wspólnego przeżywania, a tym samym tworzy wspólne wspomnienia,

- uczenie świadomości ciała - wykorzystanie sportu nie jako celu samego w sobie, lecz jako środka wychowawczego,

- refleksja nad przeżywaniem, namysł, który jest niezbędny do tego, aby działanie przyniosło pożądany efekt wychowawczy,

- $\quad$ tworzenie rytuałów, które łączą wspólnotę, pomagają przetrwać kryzys,

- organizowanie przestrzeni, w której może zawiązać się wspólnota i w którą nie będzie ingerował pedagog,

- stosowanie gier przygodowych i stwarzanie sytuacji problemowych wymagających od uczestników szukania rozwiązania - jest to pewnego rodzaju moda ostatnich lat, która zakotwiczyła się w pedagogice przeżyć, jest ona również obecna w adventure education,

- włączanie do planowanych działań nowoczesnych mediów, dzięki czemu nauczanie staje się atrakcyjne dla dzieci i młodzieży,

- podkreślenie znaczenia dobrowolności uczestnictwa w działaniu - to od uczestnika zależy ostateczna decyzja, czy podejmie działanie, czy nie, instruktor może zachęcać, ale nie może zmusić,

- podkreślanie znaczenia transferu przeżyć do życia codziennego (Michl 2011: 35-40).

W praktyce, outdoor education oznacza zazwyczaj zorganizowany proces uczenia się poprzez samodzielne doświadczenie oraz eksperymentowanie, najczęściej w ramach edukacji nieformalnej. Charakterystycznymi formami wykorzystywanymi w OE są gry zespołowe na świeżym powietrzu, wędrówki i ekspedycje, wspinaczka, zadania z wykorzystaniem lin, sporty wodne, łucznictwo, budowanie tratw, wyprawy z elementami survivalu (Leśny 2014: 41). Nazywamy to 
pedagogiką przygody. Działania w kontakcie z naturalnymi problemami wymuszają aktywność, wykorzystywanie dotychczasowego doświadczenia i dają fundament dla zdobywania wiedzy i umiejętności. Środowisko naturalne determinuje postawy aktywne i twórcze. Wyrazem postawy twórczej, angażującej zdolności i siły jednostki, jest działanie. Rzadko postawa taka pojawia się samorzutnie. Potrzebna jest inspiracja wychowawcy ukierunkowująca postawy dzieci i młodzieży (Gawlina 2001). Nauczyciel występuje zazwyczaj w roli towarzysza, mentora, trenera - a rzadziej osoby podającej wiedzę (Sendecka 2017: 6).

Jednym ze skutecznych czynników aktywizujących dzieci w każdym wieku jest kontakt z przyrodą, która jest bogatym źródłem przeżyć, wrażeń, doznań. Bezpośrednie zetknięcie dziecka z przyrodą wywołuje u niego chęć aktywnego działania, a także budzi uczucia opiekuńczości i przyjaźni wobec świata roślin i zwierząt. W zbliżaniu do przyrody dzieci przedszkolnych i z edukacji wczesnoszkolnej szczególnie ważne jest uczenie się przez przeżywanie (Sendecka 2017: 3).

Przygotowanie nauczycieli do prowadzenia zajęć z wykorzystaniem outdoor education jest istotne $\mathrm{z}$ punktu widzenia organizacji procesu edukacyjnego. Zakłada się, że aktywności w ramach pedagogiki przygody podejmowane są dobrowolnie w ramach edukacji nieformalnej. Sama przygoda, jako podstawowe pojęcie outdoor education, definiowana jest jako przeżycie w czasie wolnym, czyli poza obowiązkami. Wiąże się to z umiejętnościami nauczyciela, które pozwolą na takie zaciekawienie dzieci, aby dobrowolnie podejmowały zaplanowany wysiłek. Często mówimy o realizacji elementów outdoor education podczas zajęć szkolnych, mając na uwadze obowiązkowość działań i realizację podstawy programowej. Należy pamiętać, że realizacja tej pedagogiki to nie tylko podejmowanie akcji na świeżym powietrzu. Przeżycie związane z odkrywaniem świata można zorganizować, planując lekcje poza klasą szkolną w muzeach, teatrach, podczas happeningów. Ważne jest, aby działanie było związane z kształtowaniem umiejętności funkcjonowania w grupie rówieśniczej, pracy zespołowej i odpowiedzialności za siebie i zespól. Aktywność poza murami szkoły pozwala na uczenie się w warunkach i sytuacjach, które częściowo tylko mogą być zaplanowane, często wymagają spontanicznego podejmowania decyzji, które determinują kształtowanie samodzielności, zaradności i wiary we własne możliwości. Colin Mortlock podkreśla, że przygoda, w której doświadcza się skrajnych emocji i czuje się odpowiedzialność za podejmowanie ryzykownych decyzji, wyzwala prawdziwe możliwości indywidualne każdego dziecka (Rębiałkowska-Stankiewicz 2016: 221). Te możliwości nigdy nie zostaną wyzwolone w systemie klasowo-lekcyjnym i podczas planowanych zabaw na świeżym powietrzu w ściśle określonych warunkach. Mortlock podkreśla konieczność indywidualizacji ryzyka, uwzględnianie doświadczenia każdego dziecka i jego rozwoju fizycznego. Filozofia przygody Mortlocka koncentruje się na zaproponowaniu istnienia czterech podstawowych „stanów przygód:

\section{Etap 1}

Gra: Charakteryzuje się niewielkimi emocjami dzięki stosunkowo łatwemu udziałowi w zajęciach poniżej poziomu umiejętności danej osoby.

\section{Etap 2}

Przygoda: Charakteryzuje się radością i podekscytowaniem, gdy osoba pełniej wykorzystuje swoje możliwości, ale osoba utrzymuje kontrolę nad sytuacją i swoją jaźnią.

\section{Etap 3}

Przygoda graniczna: Charakteryzuje się szczytowym doświadczeniem, które wyłania się z osoby, która doświadcza ryzykownych wyzwań, bardzo zbliżonych do swoich ograniczeń. Jeśli dana osoba odniesie sukces, generalnie osiąga szczytowe doświadczenie, ale istnieje realne ryzyko popchnięcia zbyt daleko i upadku/niepowodzenia, prowadząc do etapu 4. 


\section{Etap 4}

Nieszczęśliwy wypadek: Charakteryzuje go osoba wybierająca lub zmuszona do uczestniczenia w wyzwaniach wykraczających poza jej możliwości, wyzwaniach powodująccy negatywne emocje (strach, zranienie itp.), ewentualnie obrażenia.

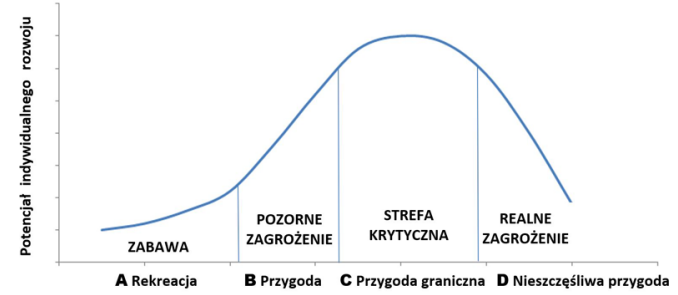

Ryc. 1. Model zależności między poziomem ryzyka a wpływem edukacyjnym aktywności „przygodowych" na uczestników Źródło: Agnieszka Leśny, 2014

Rolą wychowawcy jest zorganizowanie zajęć w taki sposób, aby nie dochodziło do czwartego etapu. Zgodnie z wymaganiami indywidualizacji zadań należy chronić uczniów biorących udział w przygodzie przed podejmowaniem wyzwań przekraczających ich możliwości.

Mając na uwadze zmiany w kształceniu nauczycieli przedszkola i edukacji wczesnoszkolnej, w październiku 2018 r. przeprowadzono wśród studentów badania, których celem było zebranie opinii przyszłych nauczycieli na temat wykorzystania modelu outdoor education w kształceniu na kierunku pedagogika przedszkolna i wczesnoszkolna, z uwzględnieniem edukacji dla zrównoważonego rozwoju. Podczas badania starano się zebrać materiał pozwalający na rozwiązanie problemów szczegółowych:

1. jaka jest wiedza studentów na temat outdoor education;

2. jak studenci definiują pojęcie rozwoju zrównoważonego;

3. jakie, zdaniem studentów, są korzyści ze stosowania outdoor education w edukacji dla zrównoważonego rozwoju dzieci przedszkolnych i wczesnoszkolnych;

4. jakie są potrzeby studentów w zakresie przygotowania do stosowania modelu outdoor education w edukacji.

W badaniu uczestniczyli studenci kierunku pedagogika o specjalności edukacja przedszkolna i wczesnoszkolna z Białegostoku. Populacja uczestników badań wynosiła - 95 osób, w tym:

- II rok studiów I stopnia - 44 osoby,

- III rok studiów I stopnia - 25 osób,

- $\quad$ studia podyplomowe - 26 osó.b

\section{Analiza i interpretacja wyników}

Wiedza studentów na temat outdoor education jest bardzo mała.

Zapytano studentów: Czy spotkali się z tym pojęciem lub z podobnymi (ryc. 2 i 3 ).

Badanie ujawniło, iż pojęcie outdoor education jest znane tylko przez 32\% respondentów, 68\% badanych nie słyszało o tym terminie. Najbardziej rozpoznawalne jest pojęcie edukacja poza klasą - 69\%. Znajomość pojęcia zrównoważonego rozwoju deklaruje 50\% badanej populacji studentów. Stopień znajomości tego pojęcia jest determinowany etapem kształcenia: w najmniejszym stopniu jego znajomość deklarują studenci II roku studiów licencjackich, następnie studenci III roku, a w największym stopniu słuchacze studiów podyplomowych. Fakt ten można wytłumaczyć tym, że na III roku studiów pojawia się przedmiot dotyczący metodyki prowadzenia edukacji przyrodniczej, w którym poruszane jest to zagadnienie.

Jeżeli chodzi o edukację poprzez przygodę czy edukację przygody, to studenci postrzegają te pojęcia jednakowo ( $45 \%$ respondentów).

W kolejnym pytaniu - Jak rozumiesz ideę zrównoważonego rozwoju? - zweryfikowano deklaracje studentów na ten temat. Okazało się, że wśród 50\% badanych studentów, którzy w poprzednim pytaniu sygnalizowali znajomość pojęcia, nie wszyscy interpretują je prawidłowo. 40\% tej grupy uważa, że zrównoważony rozwój to 


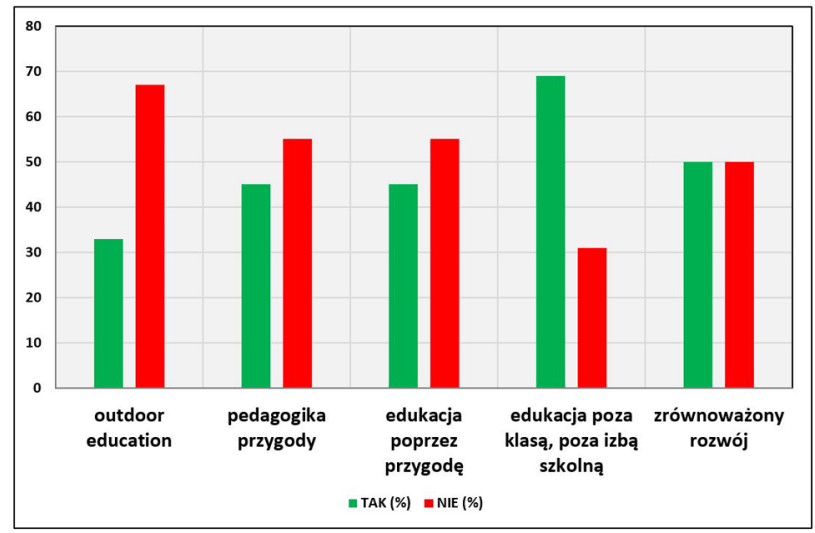

Ryc. 2. Wiedza studentów na temat związany z pojęciem outdoor education Źródło: badania własne. "Dane nie sumują się, wielokrotny wybór

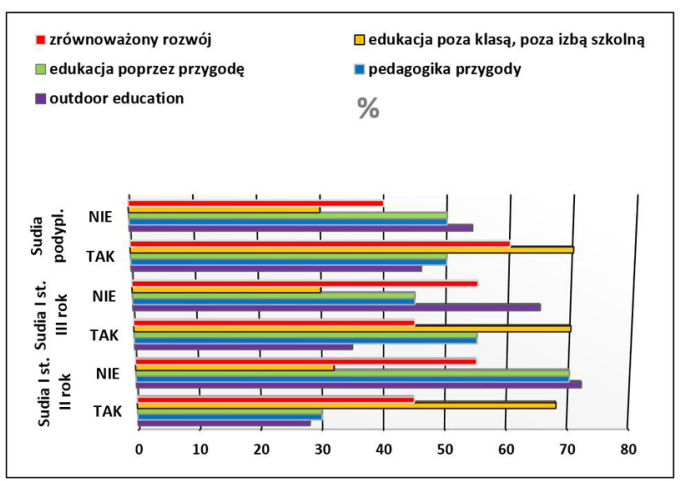

Ryc. 3. Wiedza studentów na temat związany z pojęciem outdoor education z uwzględnieniem struktury badanych

Źródło: badania własne

racjonalne gospodarowanie zasobami środowiska naturalnego, nieingerowanie w prawa przyrody, $10 \%$ opisuje pojęcie jako wszechstronny rozwój dziecka na wszystkich płaszczyznach jednocześnie. Pozostałe osoby nie udzielały żadnej odpowiedzi na to pytanie. Studenci przygotowujący się do zawodu nauczyciela edukacji wczesnoszkolnej i przedszkolnej w większości posiadają wiedzę, że zajęcia poza klasą dotyczą nie tylko edukacji przyrodniczej (59\%), 24\% badanych łączy pojęcie tylko z edukacją przyrodniczą, a 17\% respondentów nie ma zdania na ten temat.

Kolejne pytanie brzmiało: Co Twoim zdaniem daje uczniom praca poza klasą szkolną?, a udzielone odpowiedzi obrazuje ryc. 4.

W opinii badanych studentów praca z uczniami poza klasą szkolną pozwala na rozwój wartości i zainteresowań. Tak uważa $78 \%$ respondentów. Według $67 \%$ badanych osób taka praca sprawia, że jest większa motywacja do pracy oraz że wpływa na rozwój funkcji społecznych (58\%). Na lepszą koncentrację wskazuje $42 \%$ badanych.

W badaniu zgromadzono informacje na temat kompetencji społecznych, które w opinii studentów mogą być kształtowane i rozwijane podczas zajęć poza klasą szkolną (ryc. 5). 


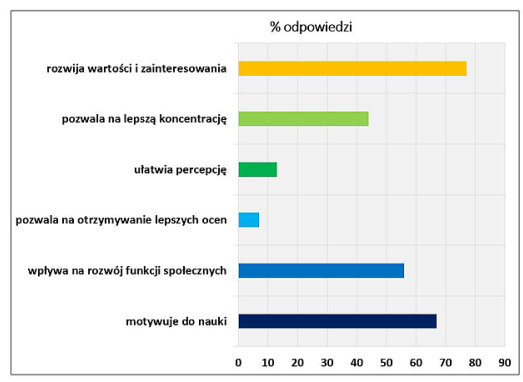

Ryc. 4. Korzyści z organizowania pracy poza klasą szkolną

Źródło: badania własne. "Dane nie sumują się do 10o. Wielokrotny wybór

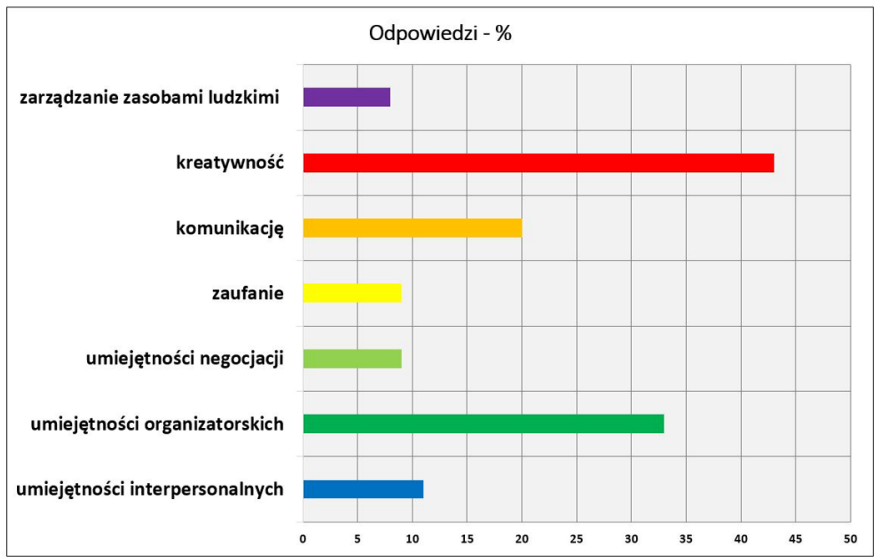

Ryc. 5. Kompetencje społeczne kształtowane i rozwijane podczas zajęć poza klasą szkolną

Źródło: badania własne

Na podstawie danych uzyskanych w wyniku prowadzonych badań można wnosić, że podczas zajęć w terenie w największym stopniu jest rozwijana kreatywność uczniów 44\%, umiejętności organizatorskie - 33\%, komunikacyjne - $20 \%$ i związane z tym interpersonalne $-\mathbf{1 1} \%$. Potwierdzano również umiejętności inicjacyjne i zaufanie (w równym stopniu - po 9\% wskazań).

Kolejne pytanie brzmiało: Czy czujesz się przygotowana/y do prowadzenia zajęć terenowych z dziećmi? (dane, ryc. 6).

Badania jednoznacznie wskazują, że najbardziej przygotowani do prowadzenia zajęć terenowych są studenci studiów podyplomowych (68\%), następnie studenci III roku studiów licencjackich (49\%), a w najmniejszym stopniu studenci II roku (11\%).
W zawiązku z ujawnionymi potrzebami związanymi z doskonaleniem umiejętności prowadzenia zajęć $\mathrm{w}$ terenie bardzo istotne wydają się dane uzyskane z odpowiedzi studentów na pytanie: Jakie działania podjęte przez uczelnię przyczyniłyby się do zwiększenia kompetencji w zakresie prowadzenia zajęć w terenie? (dane, ryc. 7).

Respondenci w badaniu zaproponowali również materiały metodyczne, które w ich ocenie, ułatwiłyby przygotowanie do zajęć terenowych z edukacji przyrodniczej. Są to (układ hierarchiczny): gry dydaktyczne, głównie plenerowe, podstawowe informacje na temat roślin i zwierząt, klucze i atlasy do rozpoznawania gatunków roślin i zwierząt, karty pracy dla uczniów, informacje o wybranych ekosystemach, ciekawostki 


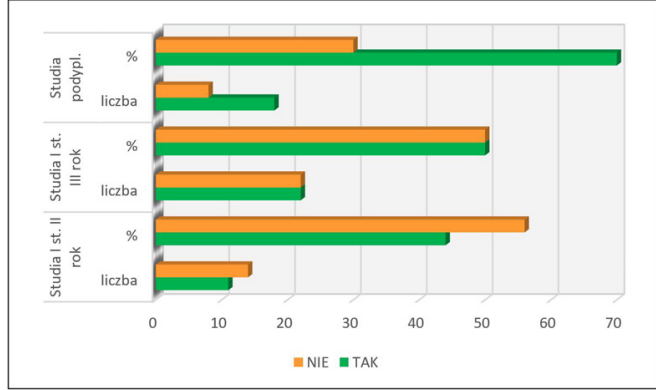

Ryc. 6. Opinie studentów na temat przygotowania do prowadzenia zajęć terenowych

Źródło: badania własne

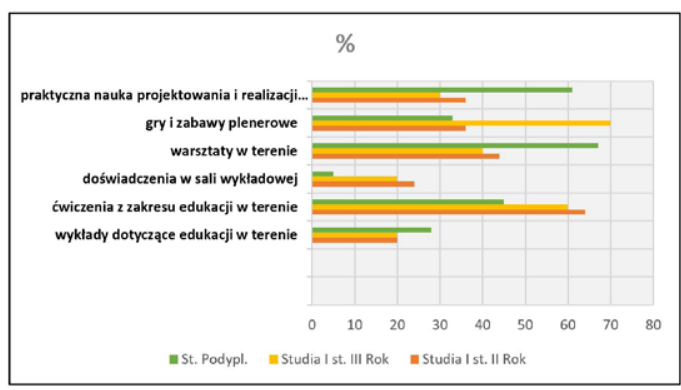

Ryc. 7. Propozycje studentów na pracę uczelni w kierunku rozwijania kompetencji prowadzenia zajęć terenowych

Źródło: badania własne

o organizmach żywych, prezentacje problemów ekologicznych, scenariusze zajęć.

Na podstawie odpowiedzi na kolejne pytanie - Co Twoim zdaniem jest podczas tych zajęć najtrudniejsze? - można wnioskować, że największym problemem studentów związanym z prowadzeniem zajęć terenowych jest zapewnienie uczniom bezpieczeństwa (dane, ryc. 8). Tak twierdzi 72\% studentów studiów podyplomowych, 60\% studentów III roku studiów licencjackich oraz $58 \%$ studentów II roku studiów licencjackich. W następnej kolejności, dla studentów III roku obawy budzą:

- konieczność posiadania szerokiej wiedzy przyrodniczej (40\%),

- umiejętność prowadzenia zajęć w terenie $(40 \%)$,

- umiejętność wykorzystania naturalnych środków dydaktycznych (10\%),

- pomysły na zajęcia terenowe (10\%).

Studenci II roku zauważają, że oprócz wspomnianego wcześniej bezpieczeństwa, ważne są:

- umiejętność wykorzystania naturalnych środków dydaktycznych (46\%),

- $\quad$ pomysły na zajęcia terenowe (38\%),

- umiejętność prowadzenia zajęć w terenie $(33 \%)$,

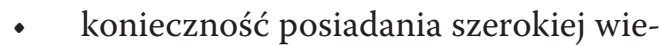
dzy przyrodniczej (29\%).

Natomiast studenci studiów podyplomowych za problemy związane z prowadzeniem zajęć w terenie uważają:

- konieczność posiadania szerokiej wiedzy przyrodniczej (33\%),

- pomysły na zajęcia terenowe (33\%),

- umiejętność prowadzenia zajęć w terenie $(28 \%)$,

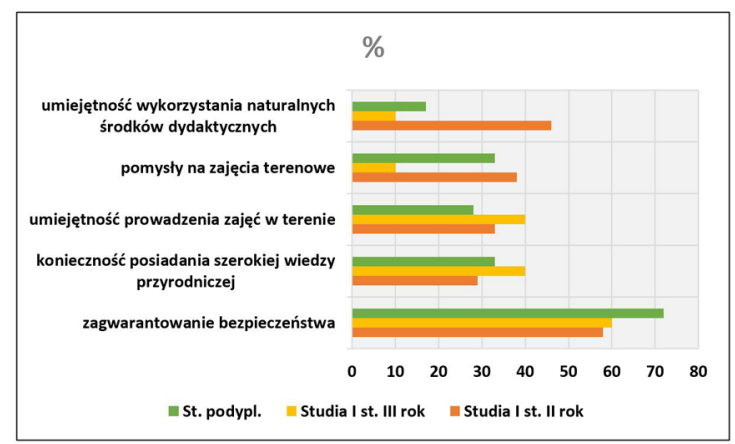

Ryc. 8. Opinie studentów na temat trudności związanych z prowadzeniem zajęć w terenie 
- umiejętność wykorzystania naturalnych środków dydaktycznych (17\%).

Powyższe opinie zostały potwierdzone danymi uzyskanymi w wyniku odpowiedzi na kolejne pytanie: Czy Twoim zdaniem w trakcie studiów powinny być prowadzone zajęcia w terenie? Aż $72 \%$ respondentów uważa, że w trakcie studiów powinny być prowadzone takie zajęcia (ryc. 9).

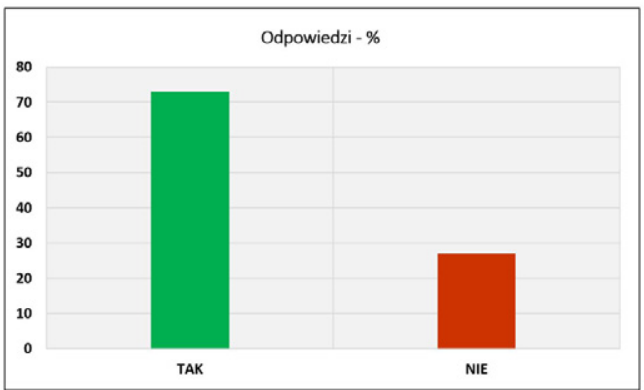

Ryc. 9. Opinie studentów na temat wprowadzenia zajęć terenowych do programu studiów

Źródło: badania własne

Studenci uczestniczący w prezentowanym badaniu byli zdania, że umiejętności techniczne nabyte podczas zajęć poza szkołą można wykorzystać w codziennym życiu (dane, ryc. 10).

W postępowaniu badawczym zgromadzono również informacje uzyskane na podstawie danych z odpowiedzi respondentów na pytanie: W jakim stopniu poniższe rodzaje aktywności nawiązujące do survivalu mogą być przydatne do podejmowania działań w codziennym życiu? (ryc. 11).

Warto zaznaczyć, że 9o\% studentów uczestniczących w badaniu jest zdania, że outdoor education może być przydatne w procesie socjalizacji uczniów, co jest ważne z punktu wykonywania przyszłego zawodu nauczyciela edukacji wczesnoszkolnej i przedszkolnej. Ponadto wszyscy biorący udział w badaniu (100\%) studenci są zdania, że zajęcia prowadzone poza klasą mogą być atrakcyjne dla uczniów.

Podsumowując, można stwierdzić, że studentom w dużym stopniu potrzebne jest wzbogacenie merytorycznej wiedzy przyrodniczej, poza rozwojem kompetencji prakseologicznych.

Studenci nie znają pojęć związanych ze zrównoważonym rozwojem, a ci, którzy deklarują ich znajomość, nie definiują terminu prawidłowo. Mała jest także wiedza o edukacji poprzez przygodę i zabawę w terenie. Polska ma tradycje związane z realizacją zadań w obszarze edukacji nieformalnej. H. Jordan był pomysłodawcą i założycielem krakowskiego parku gier i zabaw dla dzieci i młodzieży. Uważał on, że ćwiczenia fizyczne na świeżym powietrzu wpłyną na harmonijny rozwój dzieci. Jego zajęcia na świeżym powietrzu z wykorzystaniem nowoczesnego sprzętu sportowego cieszyły się dużym powodzeniem. W zabawach na świeżym powietrzu widział ogromny potencjał kształcenia charakteru, postaw i przysposobienia do pracy w grupie (Łuczyńska 2003). Pedagogiem, który widział potencjał edukacyjny w połączeniu nauki i zabawy, był również A. Kamiński. Uważał on, że zabawa wyzwala aktywność u dzieci i młodzieży oraz zaspakaja potrzebę ruchu, poznania, radości i wspólnego przebywania. Nie były to koncepcje związane $\mathrm{z}$ formalnym kształceniem, ale wskazywały na łatwość uczenia się w warunkach przygody, zaskoczenia, ryzyka i przyjemności (Kamiński 1972). Współcześnie, zakładając konieczność realizacji podstawy programowej i kłopoty związane z rozwojem społeczno-emocjonalnym, koncentracją uwagi i zapamiętywaniem u dzieci, warto wprowadzić działania, które wspomogą proces uczenia się. Takim rozwiązaniem może być właśnie outdoor education. Kluczowe zasady outdoor education to:

- człowiek uczy się sam, a nie jest nauczany ( $\rightarrow$ konstruktywizm, neurodydaktyka),

- $\quad$ łatwiej, milej i efektywniej uczy się w grupie,

- w działaniach (grach, wyzwaniach, zadaniach) uczestnicy mają wybór. Nie ma przymusu (zasada challange by choice), 


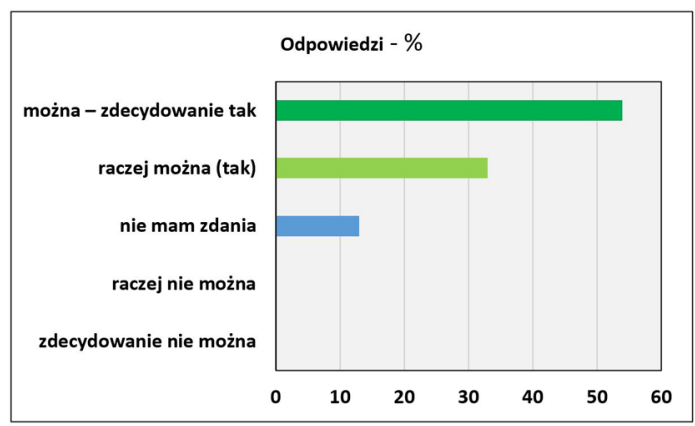

Ryc. 10. Opinie studentów na temat wykorzystania w życiu umiejętności technicznych zdobytych przez uczniów w terenie

Źródło: badania własne

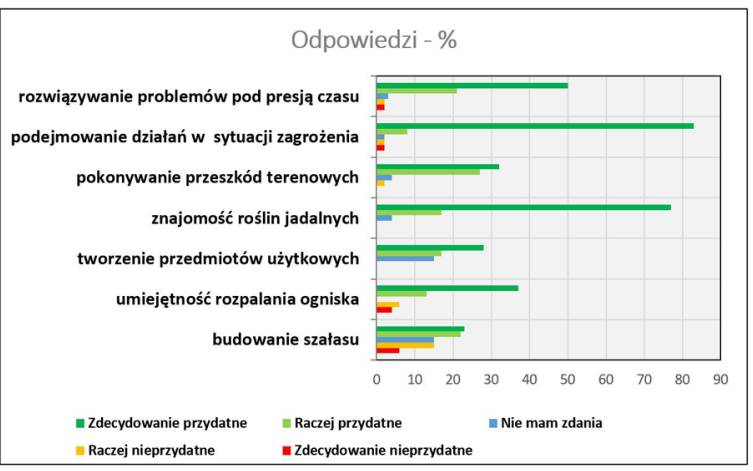

Ryc. 11. Ocena trudności podczas prowadzenia zajęć w terenie

Źródło: badania własne

- możliwie wiele treści nabywa się poprzez realne doświadczenie (zasada learning by doing),

- w uczeniu się wykorzystuje się model Cyklu Kolba, teorię stylów uczenia się, współczesną wersję tzw. Piramidy Maslowa, Paradygmat Doświadczenia Przygody Martina \& Priesta itp.,

- $\quad$ wykorzystuje się transfer wiedzy z doświadczenia (gry) do "realnego życia” za pomocą wspólnych podsumowań,

- trener jest towarzyszem, a nie „głośnikiem", z którego wydobywa się wiedza,

- proces odbywa się w bezpiecznej atmosferze (bezpieczeństwo emocjonalne, fizyczne, społeczne),

- unika się prostego oceniania na rzecz konstruktywnej informacji zwrotnej bądź oceniania kształtującego (Leśny 2014).
Podejmowane przez szkołę działania dążą do kształtowania jednostki samodzielnej, aktywnej, twórczej i umiejącej radzić sobie w niestandardowych sytuacjach. Kwiatkowski uważa, że jednym z istotnych problemów współczesnego człowieka jest brak umiejętności podejmowania decyzji i działań oraz oczekiwanie na pomoc w pokonaniu trudności. Taka postawa jest efektem braku wiary w siebie i nierozumienia sytuacji życiowych, spowodowanym odejściem od natury na korzyść otaczania się najnowszymi technologiami. Szkole pozostawione jest zadanie stworzenia warunków harmonijnego rozwoju, atmosfery akceptacji i możliwości przeżywania sukcesów i porażek. Edukacja dla zrównoważonego rozwoju powinna mieć wymiar holistyczny, polegający na prowadzeniu nauczania/uczenia się zarówno w ramach edukacji formalnej, jak 
i pozaformalnej, w ramach udziału w różnych projektach badawczych i edukacyjnych, happeningach i akcjach społecznych. Chodzi o kształtowanie kompetencji przyszłości, czyli wiedzy, umiejętności i postaw koniecznych dla świadomego, odpowiedzialnego za siebie i swoje otoczenie młodego człowieka. Jest to możliwe dzięki zwróceniu uwagi na całościowe pojmowanie środowiska jako układu stosunków przyrodniczych, ekonomicznych, społecznych, kulturowych; otwarcie drzwi szkoły do lasu, na łąkę, pole czy staw, wprowadzenie metod badawczych i skutecznych form kształcenia, takich jak: zielone szkoły, projekty edukacyjne, a przede wszystkim outdoor education. Wymaga to interdyscyplinaryzmu i aktywizujących metod pracy w procesie nauczania/uczenia się (Stoltenberg i Michelson 1999). W tej perspektywie outdoor education staje się kolejnym narzędziem wspierającym realizację edukacji dla zrównoważonego rozwoju.

\section{Bibliografia}

Gawlina Z., 2001, Kształtowanie postawy czynnej ważnym celem wychowania, w: Gawlina Z. (red.), Ksztattowanie postaw czynnych $i$ więzi środowiskowych, Wyd. UJ, Kraków.

Jelinek J.A., 2014, Jakość nauczania przyrody. Wiedza przyrodnicza studentów jako wyznacznik jakości ksztatcenia w przedszkolu i edukacji wczesnoszkolnej, Forum Akademickie, 12.

Kamiński A., 1972, Funkcje pedagogiki społecznej. Praca socjalna i kulturalna, Warszawa.

(Web-o1) Leśny A., 2014, Outdoor education, https:// naukaprzygoda.edu.pl/outdoor-education-nauka-w-terenie/ [dostęp 25.01.2019].

Leśny A., 2014, Pedagogika przyrody - konteksty teoretyczne, w: Bąk A., Leśny A., Palamer-Kabacińska
E. (red.), Przygoda w edukacji - edukacja w przygodzie, Fundacja Pracownia Nauki i Przygody, Warszawa.

Łuczyńska B., 2003, Fenomen Henryka Jordana, Wydawnictwo Uniwersytetu Jagiellońskiego, Kraków. Michl W., 2011, Pedagogika przeżyć, WAM, Kraków. Rębiałkowska-Stankiewicz M. 2016, Wykorzystanie edukacji przygoda $w$ radzeniu sobie ze stresem choroby nowotworowe, Kwartalnik Pedagogiczny, 2, Warszawa.

Sendecka Z., 2017, Style uczenia się a koncepcja outdoor education $w$ kształceniu przedszkolnym, Ośrodek Rozwoju Edukacji, Warszawa.

Stoltenberg U., Michelsen G., 1999, Lernen nach der Agenda 21, w: Umweltbildung: den Möglichkeitssinn wecken, Strohschneider R. (ed.), Alfred Toepfer Akademie für Naturschutz, 45-54.

Strumińska-Doktór A., Doktór D.D., 2016, Atrakcyjność obszarów zielonych $w$ dzielnicy Wola dla potrzeb wypoczynku nauczycieli i uczniów, Studia Ecologiae et Bioethicae, 14, 3, 25-45.

\section{Akty prawne}

Rozporządzenie MEN z 14 lutego 2017 r. w sprawie podstawy programowej wychowania przedszkolnego oraz podstawy programowej kształcenia ogólnego dla szkoły podstawowej, w tym dla uczniów z niepełnosprawnością intelektualną w stopniu umiarkowanym lub znacznym, kształcenia ogólnego dla branżowej szkoły I stopnia, kształcenia ogólnego dla szkoły specjalnej przysposabiającej do pracy oraz kształcenia ogólnego dla szkoły policealnej (Dz.U. 2017, poz. 356)

Zalecenie Rady z 22 maja 2018 r. w sprawie kompetencji kluczowych w procesie uczenia się przez całe życie (Dz.Urz. UE 2018/C 189/o1), https://eur-lex. europa.eu/legal-content/PL/TXT/PDF/?uri=CELEX:32018Ho6o4(o1)\&from=en dostęp 12.11.2018 


\title{
Outdoor education to strengthen the implementation of sustainable development
}

\begin{abstract}
The disadvantage of education in the current school system is verbal communication as well as research and experiments conducted at school. Students have very few opportunities to conduct research and experience reality in a natural environment. Active participation awakens their interest and gives them a sense of authorship. Joint planning of expeditions, trips and field games is a factor that shapes bonds and trust in the group. Outdoor activities allow the discovery the interests and talents. Outdoor education (OE) has become increasingly popular and has various names in Poland, such as outdoor education, non-classroom education, field education, field classes and adventure pedagogy. During the field classes, children acquire both knowledge and skills. The basics are group activities, including outdoor team games. Natural obstacles are used, and the natural environment contains a wealth of teaching aids. Outdoor learning through experiencing reality allows for understanding the laws of nature, which clearly generate an approach of sustainable development in human life.

Unfortunately, students are not prepared to undertake outdoor tasks, and young teachers rarely organise trips, considering them recreation and breaks from learning rather than as opportunities to learn. Teacher awareness of new trends in education, including outdoor education, is growing, but the competencies related to conducting outdoor classes have not changed along with it. The paper will present the results of research conducted among pre-school and early childhood education students in Białystok and Łódź. The objective of the research was to gather information on the OE knowledge of students and their expectations with it in the context of shaping and improving the quality of education.
\end{abstract}

\section{Keywords}

sustainable development, outdoor education 